\title{
Dialogue between the preimplantation embryo and the oviduct
}

\author{
Urban Besenfelder*, Vitezslav Havlicek and Gottfried Brem \\ Reproduction Centre Wieselburg, Institute of Animal Breeding and Genetics, University of Veterinary \\ Medicine, Veterinaerplatz 1, A-1210 Vienna, Austria
}

\begin{abstract}
Summary
Knowledge about early embryogenesis and the role of the oviduct has gained renewed interest due to increasing awareness of the impact of animal health status and performance on the susceptibility and vulnerability of early developing embryos within their microenvironment. The significance of the oviduct is best illustrated when a glance is cast at structural as well as functional features of the oviduct which regulate the serially orchestrated and well-tuned steps in early embryogenesis. A lot of work has been done in vitro to bypass the oviduct consequently resulting in steadily increasing information about the requirements of early developing embryos. However, relatively little information is available to demonstrate direct tubal effects on gametes and embryos. There is substantial evidence that the bovine oviduct provides a source of high quality embryos, our understanding of this interaction is far from complete.
\end{abstract}

\section{Introduction}

Worldwide activity in the area of embryo production in domestic ruminants, particularly cattle, is increasing (Perry 2013). This activity has the potential to significantly impact on animal breeding and precocious selection strategies. Furthermore, dealing with early developing embryos has made us aware of a tubal-dependent and embryo-specific orchestration which highlights the need for an increased understanding of reproductive physiology as well as pathology, and which inevitably confronts us with many unsolved issues and new scientific horizons.

Ovulation, fertilisation and embryo development are all serially connected processes which are well accepted to be complicated and sophisticated biological events in their own right. Not so long ago the oviduct was recognized as playing a major role in embryogenesis. On the one hand, it is a very small organ responsible for the transient passage of gametes and embryos. Its unimposing appearance conceals the multifaceted tasks accomplished by its extraordinary microenvironment for embryo development. The peculiarity of the oviduct is already manifest in its anatomy, which allows the gametes to separately enter from different sides. 
Meanwhile, there are a plethora of scientific reports describing successful in vitro embryo production (IVP), which clearly demonstrate that the contact between embryo and oviductal epithelium is not obligatory for further development i.e. for implantation and the delivery of a calf (Hasler 2014). In addition, the oviduct can be bypassed in a variety of ways, using IVPderived embryos, or using embryos cultured in vivo in temporary host recipients of different species. This raises the question of whether the interaction of the oviduct and embryo is passive or active i.e. whether the oviduct provides an environment for optimal embryo development simply driven by the ovarian cycle and independent of the presence of an embryo. In turn, an embryo may undergo an optimal development only by receiving the components obligate to overcome this early critical period. Following this hypothesis, an embryo will undergo normal development if the components are delivered and combined in the right place at the right time and dosage. This indeed would explain why the oviduct is the only evolutionary competent organ to manage the complex biodynamics required during embryo passage. Aggravating this situation, a direct contact between embryo and tubal epithelium does not really exist; during the entire oviduct migration period the zona pellucida represents a border between the embryo and tubal epithelial cells. This matrix, adapted for tubal transportation, plays an important accessory role as mediator, biological filter, protector and guarantor of the physical intactness of the embryo (Santos et al., 2008, Van Soom et al., 2010, Held et al., 2012).

It has been comprehensively demonstrated that the effect of embryo manipulation and early culture conditions become manifest along the entire pregnancy period and even later after birth of the offspring (Merton et al., 2003, Heyman 2005). Although most of the assisted reproductive technologies (ART) applied to cattle have been optimised to a level which facilitates large numbers of pregnancies and birth of calves, there is an increasing awareness of fertility problems related to in-vitro production (IVP) (Farin et al., 2010), cloning (Heyman 2005) and even artificial insemination (AI) (Diskin \& Morris 2008). From a quantitative point of view, many routes have been established to produce high numbers of embryos and calves but from a qualitative assessment point of view it is questionable to what extent embryo development occurs within the normal limits of its plasticity. All of these findings emphasize the significant impact of the oviduct during early embryogenesis. The dialogue between the preimplantation embryo and the oviduct can be best considered when looking at the (i) oviduct physiology, (ii) in vitro production systems emphasizing single (combined) factors as well as (iii) oviduct embryo interactions which will be discussed below.

\section{Physiological events during embryo passage through the oviduct}

Regnier De Graaf (1641-1673) was recognized as one of the pioneers who comprehensively described the Fallopian tubes. De Graaf depicted the oviducts as tubal elements connecting uterine horns and ovaries. He differentiated between physiologically vs. pathologically formed tubes and noted that rabbit eggs migrate through the oviduct (cited by Ankum et al., 1996). Some 300 years later, the application of biotechnology to reproduction has permitted enormous progress with a main focus on in vitro technologies associated with early embryo production. In this context, it is appropriate to take up Hunter 's concerns not to overlook the sophisticated control mechanisms underlying oviduct physiology and their potential influences on gametes and embryos (Hunter 2012).

The holistic role of the oviduct including its impact on early embryogenesis and implications for subsequent foetal development and offspring health is still not fully known. Nevertheless, many studies increasingly argue for a significant contribution of the oviduct to early embryo development (Hunter 2005, Leese et al., 2008, Hugentobler et al., 2010, Lonergan \& Fair 2014). 
Significant tasks of the oviduct are already recognizable on closer inspection of the imposing structure characterized by four main segments and four tissue layers (Kenngott \& Sinowatz 2007). Although the muscular layer consists of longitudinally, circularly or spirally oriented bundles, the myosalpinx forms a unique continuous network of randomly anastomosed and multidirectional arranged smooth muscle fibres which intertwine and dichotomize along their course (Vizza et al., 1995). Yániz et al. (2000) provided detailed insight into the microarchitecture of the bovine oviductal mucosa. The epithelial formation attracts attention by its polymorphic extensive inner surface area characterized by folds, ridges, furrows and grooves which are mainly presented in the infundibular as well as ampullar segment (Yániz et al., 2000). The oviduct is lined with epithelial mucosa cells consisting mainly of cells able to secrete (non-ciliated) nutrients or convey (ciliated) fluid, gametes and embryos. Ciliated cells are predominantly present in the infundibulum and the ampulla, whereas the isthmic region, known to consist mainly of muscular elements, has barely any ciliated cells (Koelle et al., 2009).

The oviductal fluid is composed of a complex mixture of energy substrates (Larose et al., 2012, Leese et al., 2008), ions (Hugentobler et al., 2010), amino acids (Hugentobler et al., 2010), and macromolecules (Buhi 2002, Aviles et al., 2010), which undergo dynamic changes to temporally and spatially meet the biochemical as well as physical requirements of the developing embryo. The routes through which nutrients get into the oviduct are diverse and range from passive or active transportation from blood to oviduct, to de novo synthesis in secretory cells and release into the oviduct (Leese et al., 2001). Due to the fact that the oviductal tube is in close vicinity to the uterine horn, ovary and peritoneal cavity, its fluid milieu consists not merely of substances derived from the oviduct itself, but also of follicular, uterine and peritoneal origin (Hunter et al., 2007, 2011).

Oviductal activity is regulated by hormones released during the oestrous cycle (Wijayagunawardane et al., 2001). During the oestrous cycle there is a varying secretion of fluid (Roberts et al., 1975, Janson et al., 1983), macromolecules such as oviduct specific glycoproteins (Buhi 2002, Avilés et al., 2010) and hyaluronic acid (Lee \& Ax 1984, Stojkovic et al., 2002) and a changing blood flow (Moor \& Bruce 1976, Janson et al., 1983). These cyclic changes determine the main physical characteristics of the oviduct such as viscosity of the fluid (Hunter et al., 2011, Stojkovic et al., 2002), temperature (Hunter 2005), osmolarity (Menezo \& Guerin 1997, Hunter 1994) and pH (Roberts et al., 1975) which are thought to have an effect on gamete and embryo migration, microenvironment stabilisation and immune modulation (Buhi 2002, Hunter et al., 2011). Bauersachs et al. (2003, 2004) examined key transcriptome changes in oviduct epithelium cells and illustrated that there are also marked morphological and functional changes related to the side of ovulation and to the different stages of the oestrous cycle. One of the most unsolved but intriguing issues is represented by those factors able to modulate signals such as growth factors and cytokines which act on the endocrine, paracrine, and autocrine level. Currently, there are a plethora of studies dealing with single and multiple signals; however, the oviductal course of action cannot be fully estimated and still remains an unsolved but scientifically challenging phenomenon (Wijayagunawardane \& Miyamoto 2004, Hull \& Harvey 2001). In this context the presence of cumulus cells and white blood cells liberated via ovulation might be seen as an extra source of factors able to activate intrinsic signaling pathways (Hunter 2002).

The passage through the oviduct is exclusively accomplished by muscular and ciliary activity, predominantly effected by the ovarian cycle. During oestrus, the phases of muscular activity become synchronized and frequency reaches its maximal strength. After three days there is a loss of intensity but not frequency, which culminates in relative inactivity (Ruckebusch \& Bayard 1975). The preovulatory increase of contractions of the oviductal isthmus prevents the passage of embryos through the oviduct, whereas the postovulatory elevation of progesterone decreases oviductal motility amplitude thereby allowing the embryo to pass the uterotubal junction (Spilman et al., 1978). 
Besides muscular activity, ciliated mucosa cells also account for a substantial proportion of fluid movement and embryo transportation. Even during ovulation, when the follicular fluid enters the ampulla via the infundibulum, there is the first stimulus for the increase in ciliary beat frequency to optimize ovum pick-up (Lyons et al., 2006). The beats of the cilia are coordinated and appear rhythmically at a local level, but have a range of frequencies along the entire tube. The ciliated cells of the infundibulum induce unidirectional flows resulting in the delivery of an ovum by their ciliary activities, although their beating periodicity is asynchronous (Shi et al., 2011). The early embryo seems to be capable of down-regulating the speed of transport at a local level, which increases its length of stay (Koelle et al., 2009). It was shown that in the rat oviductal ampulla, ciliary motion is capable of transporting ova in the absence of muscle contractility (Halbert et al., 1989).

\section{IVP - early embryo development without oviductal support}

For more than two decades, huge numbers of embryos have been produced using an in vitro approach. Since then this technique has undergone significant progress resulting in increasing numbers of produced and transferred embryos annually (Perry 2013).

The total IVP procedure consists of three main parts, oocyte maturation, oocyte fertilisation and embryo culture. First successes were obtained by stepwise removing oocytes and embryos ex vivo and resuming development in vitro and vice versa (Newcomb et al., 1978, Brackett et al., 1982, Xu et al., 1987, Lu et al., 1988). In all these attempts the use of bovine oviducts provided an immediate and successful assistance to bridge those parts of embryo culture which had not been fully established in vitro at that time.

Eyestone et al. (1987) performed a feasibility study by collecting embryos from superovulated heifers, embedding the zygotes and two-cell stage embryos into agar chips and transferring these complexes into the ligated oviducts of sheep. It was shown that the transfer of bovine embryos to the sheep oviduct was a promising model to promote embryo development. This application was replicated by many authors using ovine and rabbit oviducts for in vivo culture of bovine embryos (Boland 1984, Sirard et al., 1985, Lawson et al., 1972, Lazzari et al., 2010) as well as for other species to provide suitable culture conditions during embryo transport over long distances (Allen et al., 1976, Lazzari et al., 2010). The production of embryos completely in vitro has approached a high level of optimisation yielding a steady increase in the numbers embryos of produced and transferred (Perry 2013). However, all studies share the scientific endeavour to take account of as many physiological factors as possible by simultaneously keeping the number of chemicals and components numerically manageable.

To date, it still remains unclear which components in particular alter embryo morphology and kinetics. This becomes evident especially when using biological fluids, cells or extracts. For this reason, chemically defined media do not display a biased or unsolicited effect on embryo culture; the specific effects of those chemicals which have been added to the media can be examined. These experimental designs allow the identification and characterization of single factors having a direct effect on embryo culture up to the blastocyst stage. In contrast to the use of chemically-defined media including ions, energy substrates, hyaluronic acid, amino acids or growth factors in a mixture close to the composition of tubal fluid, other protocols suggest supplementing additives like bovine serum albumin (BSA), oestrus cow serum (OCS) or fetal calf serum (FCS) that create culture conditions closer to physiological conditions (Lonergan et al., 1994, Holm et al., 2002, Rief et al., 2002,Stojkovic et al., 2003, Sagirkaya et al., 2007).

Keeping in mind that the use of many tested and proven biochemical substances has substantially improved IVP results, it has also become evident that the gap between in vitro 
and in vivo development has not been filled yet (Hasler 2014). Consequently, further steps towards more accurately mimicking the tubal environment have used media conditioned by granulosa cells or Vero cells (Maeda et al., 1996), two to three dimensional coculture systems (Rief et al., 2002, Rottmayer et al., 2006, Gualtieri et al., 2013), microfluidic systems (Beebe et al., 2002, Krisher \& Wheeler, 2010) or by oviduct fluid itself (Libik et al., 2002, Lloyd et al., 2009). It was also shown that the isolated mouse oviduct provides an excellent model to produce in vitro embryos. This in vitro culture model makes use of an organ system which is thought to most closely reflect embryo development obtained in the sheep or bovine oviduct.

Overall, these tremendous efforts including increasing laboratory experience and expertise has undoubtedly led to significant improvements in embryo production. However, these achievements were also associated with marked deviations from in vivo developed embryos, low predictability and reproducibility (Rizos et al., 2010b). Although new developments suggesting dynamic systems such as microfluidics provide promising technologies, they lag far behind routine application (Lonergan \& Fair, 2014).

\section{Embryo and Oviduct}

\section{Embryo-maternal communication}

To date, there is not much information available about an embryo maternal crosstalk. For gametes, a direct local effect in the oviduct has been shown. Oocytes and spermatozoa that touch the tubal epithelium effectuate changes in specific gene expression profiles and protein synthesis (Einspanier et al., 1997, Georgiou et al., 2005). There is evidence from several species that tubal transportation depends on successful fertilization of the oocyte. It is well known, for example, that the equine embryo passes through the oviduct within 5 to 6 days, whereas the oocyte remains in the oviduct (Freeman et al., 1992). In rats, the time of transportation depends on whether there is an oocyte or embryo in the oviduct. Embryos migrate much faster compared to oocytes and this phenomenon is not associated with different plasma progesterone concentrations in the blood (Villalón et al., 1982). Lee et al. (2002) reported the identification of upregulated genes in the murine oviduct caused by the presence of embryos. It is also noteworthy in this context to remember that the rabbit oviduct envelops the embryo in an extra mucin layer. This is an obligatory coat produced during oviduct migration which is necessary for uterine implantation and which renders bypassing the oviduct impossible (Murakami \& Imai, 1996).

Koelle et al. (2009) argued that the bovine oviductal epithelium is able to select viable oocytes, to generate formation of secretory cells, modify vascularization, and downregulate speed of transport. This was assessed as the first signs of embryo-maternal communication in the oviduct (Koelle et al., 2009). In contrast, Maillo et al. (2014) characterised the transcriptome of the bovine oviduct cells at the initiation of embryonic genome activation on Day 3 postoestrus in pregnant and cyclic heifers. The presence of an 8-cell stage embryo had no effect on the epithelial cells of the isthmus. However, an effect at the local site where the embryos contact the epithelial cells was not ruled out (Maillo et al., 2014), as has been shown for the endometrium (Bauersachs et al., 2009). In addition, the communication network of the oviduct constitutes something exceptional which may become evident by the presence of mediators, such as cumulus cells and granulosa-derived cells, possibly responsible for amplification of oocyte or embryonic signals to the endosalpinx and ipsilateral ovary (Hunter 2002). 
Plasticity or misrouted development

In contrast to IVP, the use of the bovine oviduct provides per se the physiological site for optimal embryo development. There is no need to search for single factors optimizing the IVP system rather than finding factors modifying the whole "animal system". Hence, research and commercial application benefits or suffers from this system depending how far the organism is exposed to changes and disorders. The early stages of embryo preimplantation development are very sensitive to perturbation (Gad et al., 2012, Seisenberger et al., 2013). The consequence of such insults can become manifest immediately (Merton et al., 2003, Diskin \& Morris 2008), during pregnancy, parturition or even later (Fleming et al., 2004, Heyman 2005, Fazeli 2011, Eckert et al., 2012). There is much evidence supporting the assumption that the oviduct recognizes the presence or even the quality of gametes and embryos leading to predetermination of both fates, that of the oviduct and of the embryo. The immediate embryo fate can be easily assessed following comparative in vivo vs. in vitro studies which have revealed deviations such as reduced cryo-resistance (Fair et al., 2001, Havlicek et al., 2010, Kuzmany et al., 2011a), morphological injury (Crosier et al., 2001, Fair et al., 2001, Rizos et al., 2002, Kuzmany et al., 2011 b), altered gene expression (Lazzari et al., 2002, 2010, Rizos et al., 2002, Tesfaye et al., 2004, Smith et al., 2009, Kepkova et al., 2011, Gad et al., 2012), chromosome abnormalities (Viuff et al., 1999) and fetal and peripartal development (Lazzari et al., 2002, Farin et al., 2010) to the detriment of in vitro produced embryos. These results emphasize that any oviduct culture favours embryo development compared to IVP (Besenfelder et al., 2010).

Many studies have been performed in order to compare in vitro culture conditions with those existing in vivo. Most of the results showed that there were no differences in embryo developmental rates (Laurincik et al., 2003); however, differences become obvious at the transcriptome level (Gad et al., 2012, Carter et al., 2010). In an extensive study, blastocyst groups were produced under alternative in vitro and in vivo culture conditions at different time points of development. The transcriptome of the blastocysts was critically influenced during the culture period. An ontological classification revealed a significant difference in expression patterns of genes related to lipid metabolism and oxidative stress response between blastocysts generated in vivo versus in vitro. This study allowed the definition of molecular mechanisms and pathways that are influenced by altered culture conditions especially during embryonic genome activation (Gad et al., 2012).

These more scientifically related results could be confirmed when performing the experiments on a herd level for studying infertility in dairy cattle. The transfer of in vitro derived embryos into oviducts of heifers vs. lactating cows, or lactating vs. dried off cows illustrated that the reproductive tract of the postpartum lactating dairy cow is compromised in its ability to support early embryo development compared with heifers or non-lactating cows, which may also explain early embryo mortality (Rizos et al., 2010a, Maillo et al., 2012).

\section{Conclusion}

Disturbances in early embryogenesis such as IVP, high milking performance, health problems and hormonal stimulation have an adverse impact on further embryo development resulting in sub-fertility, infertility and loss of pregnancy (Merton et al., 2003, Gad et al., 2011, Maillo et al., 2012). It is expected that in the near future investigations will focus on physiology as well as disturbances of early embryo development with regard to maternal recognition of the embryo including short term as well as transgenerational effects as has already been shown for laboratory animals. However, studies focusing on these factors will have to be performed 
on a large scale, which is expensive and time-consuming since altered phenotypes may only be evident in adult animals or even in the following generation(s) (Fleming et al., 2004, Fazeli 2011, Daxinger \& Whitelaw, 2012).

\section{Acknowledgement}

The authors work is currently funded by EU-FP7 (FECUND Grant agreement number 312097)

\section{References}

Allen WR, Stewart F, Trounson AO, Tischner M \& Bielanski W 1976 Viability of horse embryos after storage and long-distance transport in the rabbit. J Reprod Fertil 47 387-390.

Ankum WM, Houtzager HL \& Bleker OP 1996 Reinier De Graaf (1641-1673) and the Fallopian tube. Hum Reprod Update 2(4) 365-369.

Avilés M, Gutiérrez-Adán A \& Coy P 2010 Oviductal secretions: will they be key factors for the future ARTs? Mol Hum Reprod 16 896-906.

Bauersachs S, Blum H, Mallok S, Wenigerkind H, Rief S, Prelle K \& Wolf E 2003 Regulation of ipsilateral and contralateral bovine oviduct epithelial cell function in the postovulation period: a transcriptomics approach. Biol Reprod 68 1170-1177.

Bauersachs S, Rehfeld S, Ulbrich SE, Mallok S, Prelle K, Wenigerkind H, Einspanier R, Blum H \& Wolf E 2004 Monitoring gene expression changes in bovine oviduct epithelial cells during the oestrous cycle. J Mol Endocrin 32 449-466.

Bauersachs S, Ulbrich SE, Zakhartchenko V, Minten M, Reichenbach M, Reichenbach HD, Blum H, Spencer TE \& Wolf E 2009 The endometrium responds differently to cloned versus fertilized embryos. Proc Natl Acad Sci USA 106 5681-5686.

Beebe D, Wheeler M, Zeringue H, Walters E \& Raty S 2002 Microfluidic technology for assisted reproduction. Theriogenology 57 125-135.

Besenfelder U, Havlicek V, Kuzmany A \& Brem G 2010 Endoscopic approaches to manage in vitro and in vivo embryo development: use of the bovine oviduct. Theriogenology 73(6) 768-776.

Boland MP 1984 Use of the rabbit oviduct as a screening tool for the viability of mammalian eggs. Theriogenology 21 126-137.

Brackett BG, Bousquet D, Boice ML, Donawick WJ, Evans JF \& Dressel MA 1982: Normal development following in vitro fertilization in the cow. Biol Reprod 27 147-158.

Buhi WC 2002 Characterization and biological roles of oviduct-specific, oestrogen-dependent glycoprotein. Reproduction 123 355-362.

Carter F, Rings F, Mamo S Holker M, Kuzmany A, Besenfelder U, Havlicek V, Mehta JP, Tesfaye D, Schellander K \& Lonergan P 2010 Effect of elevated circulating progesterone concentration on bovine blastocyst development and global transcriptome following endoscopic transfer of in vitro produced embryos to the bovine oviduct. Biol Reprod 83(5) 707719.

Crosier AE, Farin PW, Dykstra MJ, AlexanderJE \& Farin CE 2001 Ultrastructural morphometry of bovine blastocysts produced in vivo or in vitro. Biol Reprod 64 1375-1385.

Daxinger L \& Whitelaw E 2012 Understanding transgenerational epigenetic inheritance via the gametes in mammals. Nat Rev Genet 13(3) 153-162.

Diskin MG \& Morris DG 2008 Embryonic and early foetal losses in cattle and other ruminants. Reprod Dom Anim 43 260-267.

Eckert JJ, Porter R, Watkins AJ, Burt E, Brooks S, Leese HJ, Humpherson PG, Cameron IT \& Fleming TP 2012 Metabolic induction and early responses of mouse blastocyst developmental programming following maternal low protein diet affecting life-long health. PLOS ONE 7(12): e52791. doi:10.1371/journal. pone.0052791

Einspanier R, Lauer B, Gabler C, Kamhuber M \& Schams D 1997 Egg-cumulus-oviduct interactions and fertilization. Adv Exp Med Biol 424 279-289.

Eyestone WH, Leibfried-Rutledge ML, Northey DL, Gilligan BG \& First NL 1987 Culture of one- and two-cell bovine embryos to the blastocyst stage in the ovine oviduct. Theriogenology 28 1-7.

Fair T, Lonergan P, Dinnyes A, Cottell DC, Hyttel P, Ward FA \& Boland MP 2001 Ultrastructure of bovine blastocysts following cryopreservation: effect of method of blastocyst production. Mol Reprod Dev 58 186-195.

Farin CE, Farmer WT \& Farin PW 2010 Pregnancy recognition and abnormal offspring syndrome in cattle. Reprod Fertil Dev 22 75-87.

Fazeli A 2011 Maternal communication with gametes and embryo: A personal opinion. Reprod Dom Anim 46 (Suppl. 2) 75-78.

Fleming TP, Kwong WY, Porter R, Ursell E, Fesenko I, Wilkins A, Miller DJ, Watkins AJ \& Eckert JJ 2004 The embryo and its future. Biol. Reprod 71 1046-1054.

Freeman DA, Woods GL, Vanderwall DK \& Weber JA 1992 Embryo-initiated oviductal transport in mares. J Reprod Fertil 95(2) 535-538.

Gad A, Besenfelder U, Havlicek V, Hölker M, Cinar MU, Rings F, Dufort I, Sirard MA \& Schellander K, Tesfaye D 2012 Transcriptome profile of bovine blastocysts derived from alternative in vivo and in vitro culture conditions at 
specific phases of early embryonic development. Reprod Fertil Dev 24 179-179.

Gad A, Besenfelder U, Rings F, Ghanem N, Salilew-Wondim D, Hossain MM, Tesfaye D, Lonergan P, Becker A, Cinar U, Schellander K, Havlicek V \& Hölker M 2011 Effect of reproductive tract environment following controlled ovarian hyperstimulation treatment on embryo development and global transcriptome profile of blastocysts: implications for animal breeding and human assisted reproduction. Hum Reprod 26 1693-1707.

Georgiou AS, Sostaric E, Wong CH, Snijders AP, Wright PC, Moore HD \& Fazeli A 2005 Gametes alter the oviductal secretory proteome. Mol Cell Proteomics 4 1785-1796.

Gualtieri R, Mollo V, Braun S, Barbato V, Fiorentino I \& Talevi R 2013 Bovine oviductal monolayers cultured under three-dimension conditions secrete factors able to release spermatozoa adhering to the tubal reservoir in vitro. Theriogenology 79(3):429-435.

Halbert SA, Becker DR \& Szal SE 1989 Ovum transport in the rat oviductal ampulla in the absence of muscle contractility. Biol Reprod 40 1131-1136.

Hasler JF 2014 Forty years of embryo transfer in cattle: a review focusing on the journal Theriogenology, the growth of the industry in North America, and personal reminisces. Theriogenology 81(1) 152-169.

Havlicek V, Kuzmany A, Cseh S, Brem G \& Besenfelder U 2010 The effect of long-term in vivo culture in bovine oviduct and uterus on the development and cryotolerance of in vitro produced bovine embryos. Reprod Dom Anim 45 832-837.

Held E, Mertens EM, Mohammadi-Sangcheshmeh A, Salilew-Wondim D, Besenfelder U, Havlicek V, Herrler A, Tesfaye D, Schellander K \& Hoelker M 2012 Zona pellucida birefringence correlates with developmental capacity of bovine oocytes classified by maturational environment, COC morphology and G6PDH activity. Reprod Fertil Dev 24(4) 568-579.

Heyman Y 2005 Nuclear transfer: a new tool for reproductive biotechnology in cattle. Reprod Nutr Dev 45(3) 353-361.

Holm P, Booth PJ \& Callesen H 2002 Kinetics of early in vitro development of bovine in vivo-and in vitro-derived zygotes produced and/or cultured in chemically defined or serum-containing media. Reproduction 123 553-565.

Hugentobler SA, Sreenan JM, Humpherson PG, Leese HJ, Diskin MG \& Morris DG 2010 Effects of changes in the concentration of systemic progesterone on ions, amino acids and energy substrates in cattle oviduct and uterine fluid and blood. Reprod Fertil Dev 22 684-694.

Hull KL \& Harvey S 2001 Growth hormone: roles in female reproduction. J Endocrinol 168(1) 1-23.

Hunter RH 2002 Vital aspects of Fallopian tube physiology in pigs. Reprod Dom Anim 37(4) 186-190.

Hunter RHF 1994 Modulation of gamete and embryonic microenvironments by oviduct glycoproteins. Mol Reprod Dev 39(2) 176-181.

Hunter RHF 2005 The Fallopian tubes in domestic mammals: how vital is their physiological activity? Reprod Nutr Dev 45(3) 281-290.

Hunter RHF 2012 Components of oviduct physiology in eutherian mammals. Biol Rev Camb Philos Soc 87 244-255.
Hunter RHF, Cicinelli E \& Einer-Jensen N 2007 Peritoneal fluid as an unrecognised vector between female reproductive tissues. Acta Obstetricia et Gynecologica 86 260-265.

Hunter RH, Coy P, Gadea J \& Rath D 2011 Considerations of viscosity in the preliminaries to mammalian fertilization. J Assist Reprod Genet 28(3) 191-197.

Janson PO, Williams D, Petrucco OM, Amato F, Seamark RF \& Findlay JK 1983 Blood flow in the ovary and adjacent structures of the non-pregnant sheep. Acta Endocrinol (Copenh). 103(2) 259-265.

Kenngott RA \& Sinowatz F 2007 Prenatal development of the bovine oviduct. Anat Histol Embryol 36 272-283.

Kepkova KV, Vodicka P, Toralova T, Lopatarova M, Cech S, Dolezel R, Havlicek V, Besenfelder U, Kuzmany A, Sirard MA, Laurincik J \& Kanka J 2011 Transcriptomic analysis of in vivo and in vitro produced bovine embryos revealed a developmental change in cullin 1expression during maternal-to-embryonic transition. Theriogenology 75(9) 1582-1595.

Koelle S, Dubielzig S, Reese S, Wehrend A, König P \& Kummer W 2009 Ciliary transport, gamete interaction, and effects of the early embryo in the oviduct: ex vivo analyses using a new digital videomicroscopic system in the cow. Biol Reprod 81 267-274.

Krisher RL \& Wheeler MB 2010 Towards the use of microfluidics for individual embryo culture. Reprod Fertil Dev 22 32-39.

Kuzmany A, Havlicek V, Brem G, Walter I \& Besenfelder U 2011b: Assessment of actin cytoskeleton and nuclei in bovine blastocysts developed under different culture conditions using a novel computer program. Reprod Dom Anim 46 e46-53.

Kuzmany A, Havlicek V, Wrenzycki C, Wilkening S, Brem G \& Besenfelder U 2011a Expression of mRNA, before and after freezing, in bovine blastocysts cultured under different conditions. Theriogenology 75(3) 482-494.

Larose J, Laflamme J, Côté I, Lapointe J, Frenette G, Sullivan R \& Bilodeau JF 2012 The polyol pathway in the bovine oviduct. Mol Reprod Dev 79(9) 603-612.

Laurincik J, Schmoll F, Mahabir E, Schneider H, Stojkovic M, Zakhartchenko V, Prelle K, Hendrixen PJ, Voss PL, Moeszlacher GG, Avery B, Dieleman SJ, Besenfelder U, Müller M, Ochs RL, Wolf E, Schellander K, MaddoxHyttel P 2003 Nucleolar proteins and ultrastructure in bovine in vivo developed, in vitro produced, and parthenogenetic cleavage-stage embryos. Mol Reprod Dev 65(1) 73-85.

Lawson RA, Rowson LE \& Adams CE 1972 The development of cow eggs in the rabbit oviduct and their viability after re-transfer to heifers. J Reprod Fertil 28 313-315.

Lazzari G, Colleoni S, Lagutina I, Crotti G, Turini P, Tessaro I, Brunetti D, Duchi R \& Galli C 2010 Short-term and long-term effects of embryo culture in the surrogate sheep oviduct versus in vitro culture for different domestic species. Theriogenology 73 748-757.

Lazzari G, Wrenzycki C, Herrmann D, Duchi R, Kruip T, Niemann H \& Galli C 2002: Cellular and molecular deviations in bovine in vitro-produced embryos are related to the large offspring syndrome. Biol Reprod $\mathbf{6 7}$ 767-775. 
Lee CN \& Ax RL 1984 Concentrations and composition of glycosaminoglycans in the female bovine reproductive tract. J Dairy Sci 67(9):2006-2009.

Lee KF, Yao YQ, Kwok KL, Xu JS \& Yeung WS 2002 Early developing embryos affect the gene expression patterns in the mouse oviduct. Biochem Biophys Res Commun 292(2) 564-570.

Leese HJ, Baumann CG, Brison DR, McEvoy TG \& Sturmey RG 2008 Metabolism of the viable mammalian embryo: quietness revisited. Mol Hum Reprod 14 667-672.

Leese HJ, Tay JI, Reischl J \& Downing SJ 2001 Formation of Fallopian tubal fluid: role of a neglected epithelium. Reproduction 121 339-346.

Libik M, Slavík T, Schwarz T, Murawski M, Ciuryk S \& Wierzchos E 2002 Influence of oviductal fluid on ovine embryo viability. Folia Biol (Praha) 48 145-148.

Lloyd RE, Romar R, Matás C, Gutiérrez-Adán A, Holt WV \& Coy P 2009 Effects of oviductal fluid on the development, quality, and gene expression of porcine blastocysts produced in vitro. Reproduction 137 679-687.

Lonergan P, Carolan C \& Mermillod P 1994 Development of bovine embryos in vitro following oocyte maturation under defined conditions. Reprod Nutr Dev 34 329-339.

Lonergan P \& Fair T 2014 The ART of studying early embryo development: progress and challenges in ruminant embryo culture. Theriogenology 81(1) 49-55.

Lu KH, Gordon I, Chen HB, Gallagher M \& McGovern H 1988 Birth of twins after transfer of cattle embryos produced by in vitro techniques. Vet $\operatorname{Rec} 122$ 539-540.

Lyons RA, Saridogan E \& Djahanbakhch O 2006 The effect of ovarian follicular fluid and peritoneal fluid on Fallopian tube ciliary beat frequency. Hum Reprod 21(1):52-56.

Maeda J, Kotsuji F, Negami A, Kamitani N \& Tominaga T 1996 In vitro development of bovine embryos in conditioned media from bovine granulosa cells and vero cells cultured in exogenous protein- and amino acid-free chemically defined human tubal fluid medium. Biol Reprod 54(4) 930-936.

Maillo V, O'Gaora P,Mehta JP,De Frutos C,Forde N,Spencer TE, Lonergan P \& Rizos D 2014 Oviductembryo interactions: two-way traffic or a one-way street? Transcriptomic response of the bovine oviduct to the presence of an embryo. Reprod Fertil Dev 26(1) 152-153.

Maillo V, Rizos D, Besenfelder U, Havlicek V, Kelly AK, Garrett M \& Lonergan P 2012 Influence of lactation on metabolic characteristics and embryo development in postpartum Holstein dairy cows. J Dairy Sci 95(7):38653876.

Menezo Y \& Guerin P 1997 The mammalian oviduct: biochemistry and physiology. Eur J Obstet Gynecol Reprod Biol 73(1) 99-104.

Merton JS, de Roos AP, Mullaart E, de Ruigh L, Kaal L, Vos PL \& Dieleman SJ 2003 Factors affecting oocyte quality and quantity in commercial application of embryo technologies in the cattle breeding industry. Theriogenology 59 651-674.

Moor RM \& Bruce NW 1976 The distribution of blood flow to the reproductive tract of anaesthetized ewes near oestrus. Acta Endocrinol (Copenh) 83(4) 794-799.

Murakami H \& Imai H 1996 Successful implantation of in vitro cultured rabbit embryos after uterine transfer: a role for mucin. Mol Reprod Dev 43(2) 167-170.

Newcomb R, Christie WB \& Rowson LE 1978 Birth of calves after in vivo fertilisation of oocytes removed from follicles and matured in vitro. Vet Rec 102 461-462.

Perry G 2013 IETS 2013 Statistics and Data Retrieval Committee Report: 2012 Statistics of embryo collection and transfer in domestic farm animals. Embryo Transfer Newsletter- IETS 31(4) 24-46

Rief S, Sinowatz F, Stojkovic M, Einspanier R, Wolf E \& Prelle K 2002 Effects of a novel co-culture system on development, metabolism and gene expression of bovine embryos produced in vitro. Reproduction 124 543-556.

Rizos D, Carter F, Besenfelder U, Havlicek V \& Lonergan P 2010a Contribution of the female reproductive tract to low fertility in postpartum lactating dairy cows. I Dairy Sci 93 1022-1029.

Rizos D, Fair T, Papadopoulos S, Boland MP \& Lonergan P 2002 Developmental, qualitative, and ultrastructural differences between ovine and bovine embryos produced in vivo or in vitro. Mol Reprod Dev 62 320-327.

Rizos D, Ramirez MA, Pintado B, Lonergan P \& GutierrezAdan A 2010b Culture of bovine embryos in intermediate host oviducts with emphasis on the isolated mouse oviduct. Theriogenology 73 777-785.

Roberts GP, Parker JM \& Symonds HW 1975 Proteins in the luminal fluid from the bovine oviduct. J Reprod Fertil 45 301-313.

Rottmayer R, Ulbrich SE, Kölle S, Prelle K, Neumueller C, Sinowatz F, Meyer HH, Wolf E \& Hiendleder S 2006 A bovine oviduct epithelial cell suspension culture system suitable for studying embryo-maternal interactions: morphological and functional characterization. Reproduction 132 637-648.

Ruckebusch Y \& Bayard F 1975 Motility of the oviduct and uterus of the cow during the oestrous cycle. I Reprod Fertil 43 23-32.

Sagirkaya H, Misirlioglu M, Kaya A, First NL, Parrish J \& Memili E 2007 Developmental potential of bovine oocytes cultured in different maturation and culture conditions. Anim Reprod Sci 101 225-240.

Santos P, Chaveiro A, Simões N \& Moreira da Silva $F$ 2008 Bovine oocyte quality in relation to ultrastructural characteristics of zona pellucida, polyspermic penetration and developmental competence. Reprod Dom Anim 43(6) 685-689.

Seisenberger S, Peat JR \& Reik W 2013 Conceptual links between DNA methylation reprogramming in the early embryo and primordial germ cells. Curr Opin Cell Biol 25(3) 281-288.

Shi D, Komatsu K, Uemura T \& Fujimori T 2011 Analysis of ciliary beat frequency and ovum transport ability in the mouse oviduct. Genes Cells 16 282-290.

Sirard M A, Lambert RD, Ménard DP \& Bedoya M 1985 Pregnancies after in-vitro fertilization of cow follicular oocytes, their incubation in rabbit oviduct and their transfer to the cow uterus. J Reprod Fertil 75 551-556.

Smith SL, Everts RE, Sung LY, Du F, Page RL, Henderson B, Rodriguez-Zas SL, Nedambale TL, Renard JP, Lewin HA, Yang X \& Tian XC 2009 Gene expression profiling 
of single bovine embryos uncovers significant effects of in vitro maturation, fertilization and culture. Mol Reprod Dev 76 38-47.

Spilman CH, Shaikh AA \& Harper MJ 1978 Oviductal motility amplitude and ovarian steroid secretion during egg transport in the rabbit. Biol Reprod 18 409-417.

Stojkovic M, Koelle S, Peinl S, Stojkovic P, Zakhartchenko V, Thompson JG, Wenigerkind H, Reichenbach HD, Sinowatz F \& Wolf E 2002 Effects of high concentrations of hyaluronan in culture medium on development and survival rates of fresh and frozen-thawed bovine embryos produced in vitro. Reproduction 124(1) 141-153.

Stojkovic M, Krebs O, Koelle S, Prelle K, Assmann V, Zakhartchenko V, Sinowatz F \& Wolf E 2003 Developmental regulation of hyaluronan-binding protein (RHAMM/IHABP) expression in early bovine embryos. Biol Reprod 68 60-66.

Tesfaye D, Ponsuksili S, Wimmers K, Gilles M \& Schellander K 2004 A comparative expression analysis of gene transcripts in post-fertilization developmental stages of bovine embryos produced in vitro or in vivo. Reprod Dom Anim 39 396-404.

Van Soom A, Wrathall AE, Herrler A \& Nauwynck HJ 2010 Is the zona pellucida an efficient barrier to viral infection? Reprod Fertil Dev 22 21-31.

Villalón M, Ortiz ME, Aguayo C, Muñoz J \& Croxatto HB 1982 Differential transport of fertilized and unfertilized ova in the rat. Biol Reprod 26(2) 337-341.
Viuff D, Rickords L, Offenberg H, Hyttel P, Avery B, Greve T, Olsaker I, Williams JL, Callesen H \& Thomsen PD 1999 A high proportion of bovine blastocysts produced in vitro are mixoploid. Biol Reprod 60 1273-1278.

Vizza E, Correr S, Muglia U, Marchiolli F \& Motta PM 1995 The three-dimensional organization of the smooth musculature in the ampulla of the human fallopian tube: a new morpho-functional model. Hum Reprod 10(9)2400-2405.

Wijayagunawardane MP \& Miyamoto A 2004 Tumor necrosis factor alpha system in the bovine oviduct: a possible mechanism for embryo transport. / Reprod Dev 50(1) 57-62.

Wijayagunawardane MP, Miyamoto A, Taquahashi Y, Gabler C, Acosta TJ, Nishimura M, Killian G \& Sato K 2001 In vitro regulation of local secretion and contraction of the bovine oviduct: stimulation by luteinizing hormone, endothelin-1 and prostaglandins, and inhibition by oxytocin. J Endocrinol 168(1) 117-130.

Xu KP, Greve T, Callesen H \& Hyttel P 1987 Pregnancy resulting from cattle oocytes matured and fertilized in vitro. J Reprod Fertil 81 501-504.

Yániz JL, Lopez-Gatius F, Santolaria P \& Mullins KJ 2000 Study of the functional anatomy of bovine oviductal mucosa. Anat Rec 260 268-278. 